\title{
Trisomy 9
}

National Cancer Institute

\section{Source}

National Cancer Institute. Trisomy 9. NCI Thesaurus. Code C84282.

A chromosomal abnormality consisting of the presence of a third copy of chromosome 9 in somatic cells. 